\title{
Histopathological Changes of the Anterior Surface Structures of Rabbit Eye after Subconjunctival Injection of Different Doses of Mitomycin C
}

\author{
Mohamed Abd El Maksoud Abd El Fatah Higazy*1, M.B.B.,Ch; Khaled Mohamed Selim¹, MD; Ehab \\ Abdelsamiea Elsheikh ${ }^{1}$, MD; Abdelnaby Saeed Ismaeel ${ }^{2}$, MD
}

*Corresponding Author:

Mohamed Abd El Maksoud aboaasr1003@gmail.com

Received for publication August 4, 2020; accepted August24, 2020; published online August 24, 2020.

Copyright 2020 The Authors published by Al-Azhar University, Faculty of Medicine, Cairo, Egypt. All rights reserved. This an openaccess article distributed under the legal terms, where it is permissible to download and share the work provided it is properly cited. The work cannot be changed in anyway or used commercially.

doi:10.21608/aimj.2020.31565.1241

${ }^{I}$ Department of Ophthalmology, Faculty of Medicine, Al-Azhar University.

${ }^{2}$ Department of Pathology, Faculty of Medicine, Al-Azhar University.

\begin{abstract}
Background: The use of topical mitomycin $\mathrm{C}$ in ophthalmology is increasing in all sub-specialties, but the risk-benefit ratio should be considered, taking into account its complications. The dose and duration of application of MMC depend on the surgery in which it is used but is still controversial.

Objective: To evaluate the changes in the normal histology of the anterior surface structures of the rabbit eye "conjunctiva, cornea and sclera" after subconjunctival injection of different doses of Mitomycin C (0.1, 0.2 and $0.4 \mathrm{mg}$ / $\mathrm{ml}$ ) after different periods (1, 7 and 14 days).

Material and Methods: A comparative prospective case-control animal study included eighteen eyes of eighteen healthy New Zealand rabbits conducted at the Faculty of Medicine, Al-Azhar Universityfrom April 2019 to October 2019.

Results: Group B and C rabbits' eyes clinically throughout the study revealed significant findings in the form of severe congestion, severe chemosis, lid edema, and lacerationswhile group A showed non-significant clinical findings. Histopathological results showed a significant decrease of the conjunctival goblet cells and scleral elastic tissues with MMC administration at different doses even the low dosefrom the $1^{\text {st }}$ to the $3^{\text {rd }}$ sacrifice in the dose and time-dependent manner. Scleral thickness showed a significant decrease after 2 weeks of MMC administration.Corneal thickness showed a non-significant decrease within different sacrifices.

Conclusion: Preoperative subconjunctival injection of MMC by $0.1 \mathrm{mg} / \mathrm{ml}$ concentration one day before, is mainly do not affects the cornea and have the least effects on the conjunctiva and the sclera.
\end{abstract}

Keywords: Mitomycin C; Rabbit eye; Conjunctiva; Cornea; Sclera

Authorship: All authors have a substantial contribution to the article.

Disclosure: The authors have no financial interest to declare in relation to the content of this article. The Article Processing Charge was paid for by the authors.

\section{INTRODUCTION}

The front of the human eye consists of clear cornea centrally and white sclera peripherally. Cornea and sclera, respectively, are covered by the corneal and conjunctival epithelia. These epithelia are nonkeratinized and stratified structures. The corneal epithelium is 5-7 cell layers thick, while the conjunctival epithelium is $3-5$ cell layers thick. These two epithelial structures are bathed in a tear film, and together they form the front surface of the eye (the ocular surface). ${ }^{1}$ Mitomycin C (MMC) is a chemotherapeutic antibiotic isolated from Streptomyces caespitosus and is a cell-cycle nonspecific alkylating agent. MMC covalently binds to and results in DNA cross-linking; thus, it has antimetabolite activity as it inhibits cellular replication in a dose-dependent manner. ${ }^{2}$ The use of MMC was first reported in the eye to treat pterygia in
1963. It has become increasingly popular in ophthalmology because of its properties as a modulator for wound healing as well as for the treatment of pterygia, it is also used in glaucoma drainage, corneal and conjunctival dysplasia, and neoplasia, allergic eye disease, and as a measure to prevent and treat haze formation in corneal refractive surgery. ${ }^{3} \mathrm{MMC}$ is an alkalizing agent and a potent fibroblast inhibitor that causes irreversible damage to the cell's DNA structure. It inhibits both fibroblast migration and the synthesis of new collagen and thus affects wound healing. Subconjunctival MMC is known to reduce the number of stromal fibroblast cells. There is also morphological and structural damage to vascular endothelial cells. ${ }^{4}$

Because of its anti-fibroblast effect, MMC is used in a variety of ocular surgical procedures. The optimal dose of MMC is not known but is usually used at a concentration of $0.1 \mathrm{mg} / \mathrm{ml}(0.01 \%)$ to $0.5 \mathrm{mg} / \mathrm{ml}$ $(0.05 \%)$ in various clinical setups. ${ }^{5}$ Despite the 
important function of MMC in the treatment of eye diseases such as pterygium and glaucoma, complications may occur, including corneal edema, corneal melting and perforation, corneal blood staining, pigmentation, scleral calcification and melting, secondary glaucoma, prolonged hyperemia, late hemorrhage, chemosis, lid oedema, excessive tearing, ptosis, photophobia, and endophthalmitis. ${ }^{6}$ Preoperative use of MMC as a subconjunctival injection into the body of pterygium before surgical excision is another modality in which the recurrence rate is similar to intraoperative use of MMC. Subconjunctival injection of MMC avoids direct MMC contact with corneal and conjunctival epithelium, which can cause a permanent corneal or conjunctival defect. ${ }^{7}$ Compared to intraoperative use of MMC, the preoperative subconjunctival injection into the body of pterygium is preferable because its concentration is not diluted in the tear film, there is less intraocular penetration as the corneal epithelium is intact, and as a result, there is more prolonged contact time with the subconjunctival tissue. ${ }^{8}$

This study had evaluated the changes in the normal histology of the anterior surface structures of the rabbit eye "conjunctiva, cornea and sclera" after subconjunctival injection of different doses of Mitomycin C (0.1, 0.2 and $0.4 \mathrm{mg} / \mathrm{ml})$ after different periods (1, 7 and 14 days).

\section{MATERIAL AND METHODS}

A comparative prospective case-control animal study included eighteen eyes of eighteen healthy adult New Zealand white male rabbits, weighing approximately 2.0-4.0 kg. It was carried outfrom April 2019 to October 2019 at Pathology Department, Faculty of Medicine, Al-Azhar University.

Eighteen rabbits were divided into 3 groups each group contains six rabbits. The three groups (group $\mathrm{A}$, group $\mathrm{B}$, and group $\mathrm{C}$ ) were given a subconjunctival injection of $0.2 \mathrm{ml}$ MMC with different concentrations $(0.1,0.2$, and $0.4 \mathrm{mg} / \mathrm{ml}$ respectively) $2 \mathrm{~mm}$ from the limbus at 3 O'clock position in the left eye of every rabbit. Another control group was formed from six eyes from the right eyes that had not been treated with MMC. The rabbits were anesthetized with ketamine hydrochloride $(50 \mathrm{mg} / \mathrm{kg})$ and xylazine hydrochloride $(5 \mathrm{mg} / \mathrm{kg}$ ) before subconjunctival injections.

Histopathology: Six rabbits (two from each group) were sacrificed at 1 day, another six rabbits (two from each group) at 7 days, and the last six rabbits (two from each group) at 14 days. Eyes were enucleated, fixed immediately in formaldehyde $10 \%$. The globes have then bisected vertically. The specimens had embedded in paraffin and sectioned with a microtome. Sections $(5-7 \mu \mathrm{m})$ were stained with hematoxylin-eosin (H\&E) for cellularity including fibroblast, Periodic acid-Schiff (PAS) for goblet cell identification, Masson's Trichrome (MT) for collagen density and architecture and Orcein stain for elastic fiber detection. The grading system to assess cellularity, collagen deposition and goblet cells number will be calculated using the average cells number.
Statistical analysis: Data from different groups along the three sacrifices were collected, revised, encoded, and entered in the GraphPad Prism Version 7.0 (Two Way ANOVA Test) statistical package. Quantitative data were presented as mean, standard deviations, and ranges when their distribution was parametric. Qualitative variables have also been presented as numbers and percentages. The $\mathrm{p}$-value was thus found to be significant as follows: $\mathrm{P}>0.05$ : nonsignificant, $\mathrm{p}<0.05$ : significant, $\mathrm{P}<0.01$ : highly significant.

\section{RESULTS}

Immediately after injection: All of the treated rabbit eyes showed in the injected area a bubble-like elevation appeared immediately after injection, which gradually vanished within the next 1-2 days. There was no evidence of corneal stromal edema. The sclera appeared normal, specifically, without inflammatory infiltrates or scarring

During the follow up: Group A: Rabbits treated with a low dose of MMC $(0.1 \mathrm{mg} / \mathrm{ml})$ showed nonsignificant findings except that one rabbit showed slight conjunctival congestion after one day of injection and disappeared three days later. Group B: This group showed more apparent findings, all injected rabbits showed conjunctival congestion from the second day of injection. Two rabbits of them showed blepharospasm with excessive tearing in the treated eyes for about 48 hours (Figure 1).

Group C: Compared to the other groups, there were more significant clinical findings, all rabbits showed severe congestion, blepharospasm, and excessive tearing. Furthermore, two rabbits showed severe chemosis, lid edema, and lacerations. Injected eye of one of them showed scleral Dellen (Figure 2).

Corneal thickness: There were non-significant changes in the total corneal thickness within the different sacrifices unless the $3^{\text {rd }}$ sacrifice after two weeks, administration of high doses of MMC showed a marked decrease in the corneal thickness (Table 1) (Figure 3).

Keratocytes count: There were no significant changes in the count of keratocytes in different sacrifices unless there was a marked decrease in high doses of MMC $(0.4 \mathrm{mg} / \mathrm{ml})$ during the third sacrifice after two weeks of injection.

Scleral thickness: Comparing the changes of the Scleral thickness in the three study groups and the control group with variable doses of MMC along with the three different sacrifices. Scleral thickness was markedly decreased at the $3^{\text {rd }}$ sacrifice in comparison with the $1^{\text {st }}$ and $2^{\text {nd }}$ sacrifices $(\mathrm{P}<0.01)$ in all study groups. Group A results showed a nonsignificant decrease in the thickness of the sclera except in the $3^{\text {rd }}$ sacrifice $(\mathrm{P}<0.01)$ (Figure 4$)$.

Conjunctival goblet cells counting: Administration of MMC at different doses even the low dose significantly decreased the goblet cells in time and dose-dependent manner $(\mathrm{P}<0.01)$ (Figure 5).

Hematoxylin and Eosin (H\&E) stain: $1^{\text {st }}$ sacrifice showed non-significant findings except within group C conjunctival sections. $2^{\text {nd }}$ and $3^{\text {rd }}$ sacrifices showed 
significant changes mainly in conjunctival and scleral sections of groups B and C(Figure 6).

Periodic acid-Schiff (PAS) stain:Goblet cells stained with PAS showed a significant decrease with MMC administration at different doses even the low dose from the $1^{\text {st }}$ to the $3^{\text {rd }}$ sacrifice in the dose and timedependent manner (Figure 7).

Masson's Trichrome (MT) stain:The intensity of collagen staining within corneal stroma showed nonsignificant decreased in all groups of the three sacrifices.

While episcleral and scleral collagen content showed a significant decrease of the in the dose and time- dependent manner in all treated groups from $1^{\text {st }}$ to $3^{\text {rd }}$ sacrifices (Figure 8).

Orcein stain:The elastic tissues within the scleral portion were markedly decreased from the $1^{\text {st }}$ to the $3^{\text {rd }}$ sacrifice and within all treated groups in a dose and time-dependent manner (Figure 9).

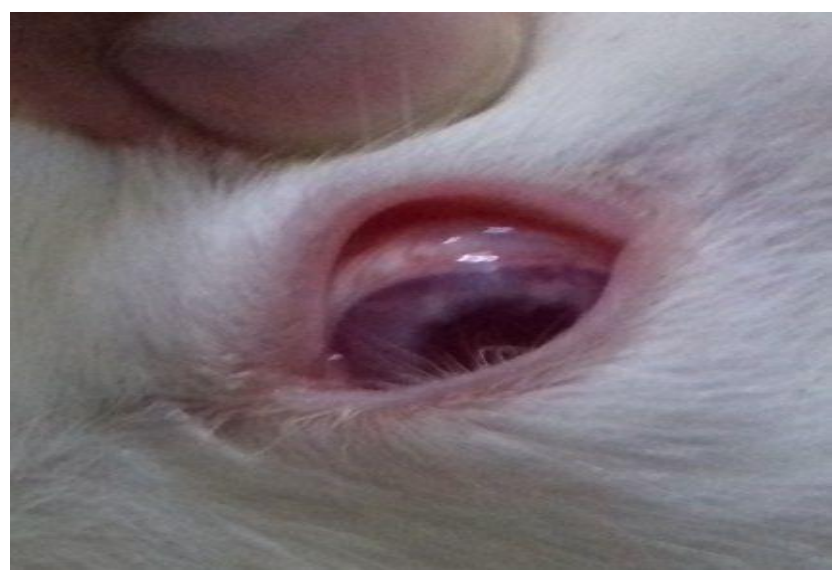

(a)

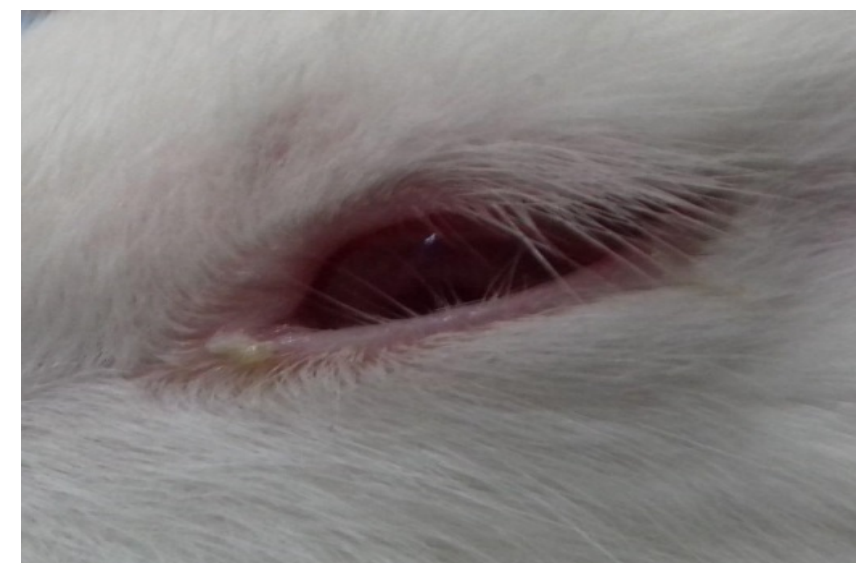

(b)

Fig. 1: Group B rabbit eyes. a; conjunctival congestion. b; blepharospasm and excessive tearing.

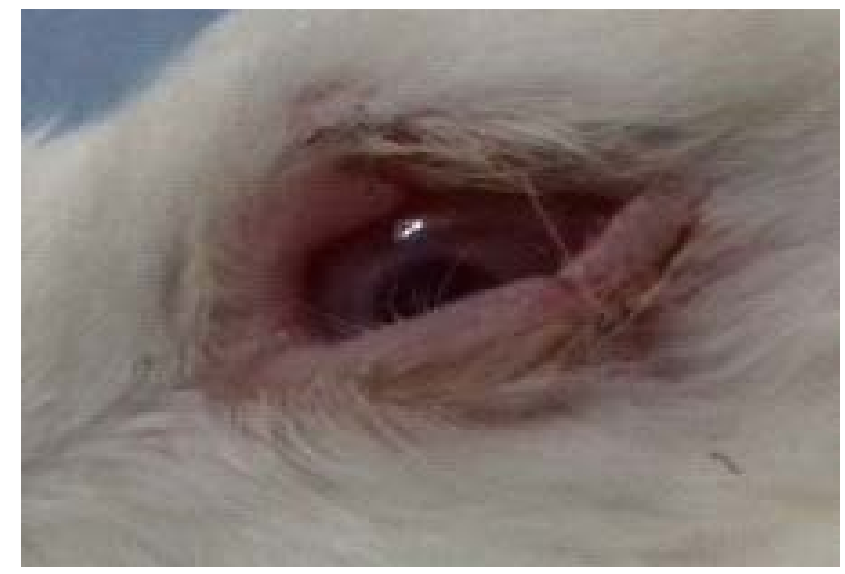

(a)

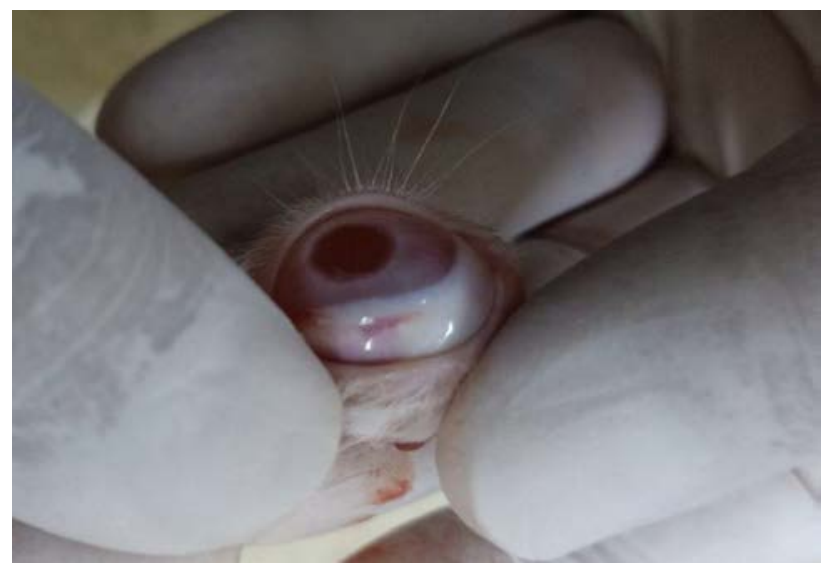

(b)

Fig. 2: Group C rabbit eyes. a; severe chemosis, lid edema, and lacerations. b; scleral dellen. 


\begin{tabular}{|c|c|c|c|c|c|c|c|c|c|c|c|c|}
\hline & \multicolumn{4}{|c|}{$\begin{array}{l}\text { First sacrifice } \\
\text { (after one day) }\end{array}$} & \multicolumn{4}{|c|}{$\begin{array}{l}\text { Second sacrifice } \\
\text { (after one week) }\end{array}$} & \multicolumn{4}{|c|}{$\begin{array}{c}\text { Third sacrifice } \\
\text { (after two weeks) }\end{array}$} \\
\hline & 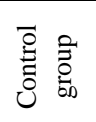 & $\begin{array}{c}\text { Group } \\
\text { A }(0.1 \\
\mathrm{mg} / \mathrm{ml})\end{array}$ & $\begin{array}{c}\text { Group } \\
\text { B }(0.2 \\
\mathrm{mg} / \mathrm{ml})\end{array}$ & $\begin{array}{c}\text { Group } \\
\mathrm{C}(0.4 \\
\mathrm{mg} / \mathrm{ml})\end{array}$ & 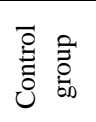 & $\begin{array}{c}\text { Group } \\
\text { A }(0.1 \\
\mathrm{mg} / \mathrm{ml})\end{array}$ & $\begin{array}{c}\text { Group } \\
\text { B }(0.2 \\
\mathrm{mg} / \mathrm{ml})\end{array}$ & $\begin{array}{c}\text { Group } \\
\mathrm{C}(0.4 \\
\mathrm{mg} / \mathrm{ml})\end{array}$ & 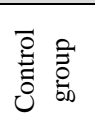 & $\begin{array}{c}\text { Group } \\
\mathrm{A}(0.1 \\
\mathrm{mg} / \mathrm{ml})\end{array}$ & $\begin{array}{c}\text { Group } \\
\text { B }(0.2 \\
\mathrm{mg} / \mathrm{ml})\end{array}$ & $\begin{array}{c}\text { Group } \\
\mathrm{C}(0.4 \\
\mathrm{mg} / \mathrm{ml})\end{array}$ \\
\hline 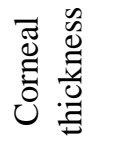 & $\begin{array}{l}235.54 \\
\pm 2.32\end{array}$ & $\begin{array}{l}233.68 \\
\pm 2.86\end{array}$ & $\begin{array}{l}234.11 \\
\pm 3.50\end{array}$ & $\begin{array}{l}225.86 \\
\pm 4.06\end{array}$ & $\begin{array}{l}238.78 \\
\pm 4.65\end{array}$ & $\begin{array}{l}232.38 \\
\pm 2.75\end{array}$ & $\begin{array}{l}229.25 \\
\pm 1.59\end{array}$ & $\begin{array}{l}223.67 \\
\pm 7.49\end{array}$ & $\begin{array}{l}240.39 \\
\pm 3.25\end{array}$ & $\begin{array}{l}231.34 \\
\pm 1.69\end{array}$ & $\begin{array}{l}227.02 \\
\pm 3.31\end{array}$ & $\begin{array}{l}217.29 \\
\pm 2.22\end{array}$ \\
\hline $\begin{array}{c}\text { Test } \\
\text { value }\end{array}$ & & 0.7106 & 0.5445 & 3.693 & & 2.441 & 3.636 & 5.765 & & 3.451 & 5.098 & 8.813 \\
\hline P-value & & 0.5510 & 0.6826 & 0.0050 & & 0.0504 & 0.0054 & 0.000 & & 0.0073 & 0.0002 & 0.000 \\
\hline Sig. & & ns & ns & $*$ & & ns & $*$ & $* *$ & & $*$ & $* *$ & $* * *$ \\
\hline
\end{tabular}

Two-way ANOVA test

Data of corneal thickness are expressed as mean \pm standard deviation.

Table 1:Comparison of the corneal thickness in the three study groups and control group with variable doses of MMC along with the three different sacrifices.

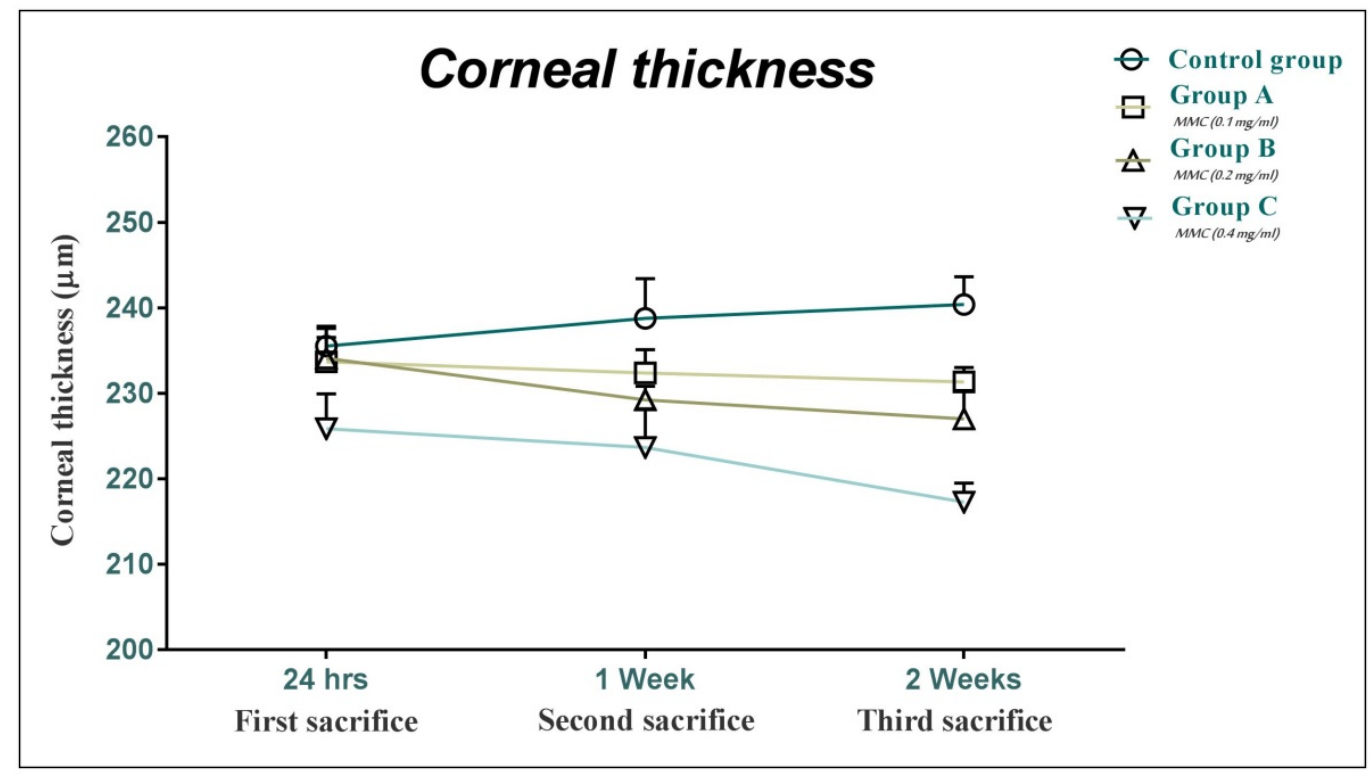

Fig. 3: A chart showing corneal thickness within the different sacrifices at different doses of mitomycin, data were expressed as mean $\pm \mathrm{SE}$. 


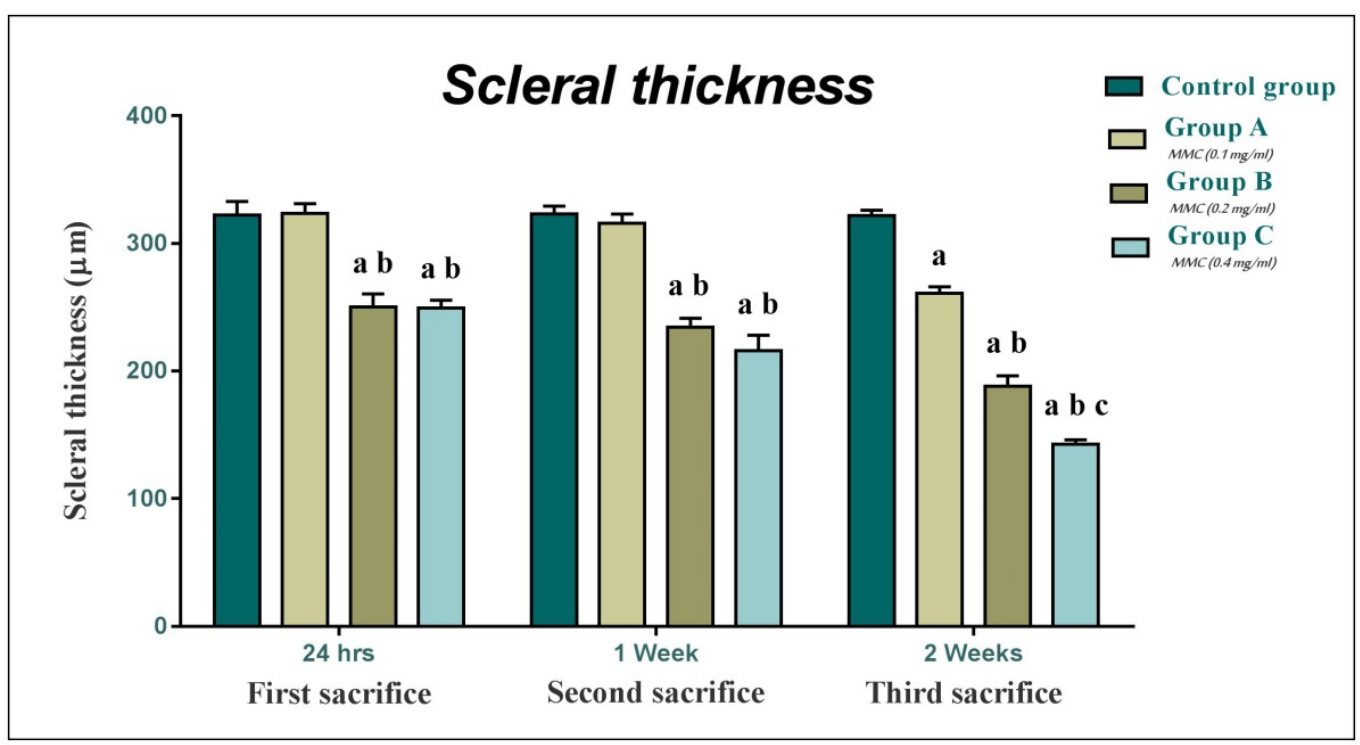

Fig. 4:A chart showing scleral thickness within the different sacrifices at different doses of mitomycin, data were expressed as mean \pm SE. a indicates significance incomparing with the control group, b indicates significance incomparing with group $\mathrm{A}, \mathrm{c}$ indicates significance incomparing with group B.

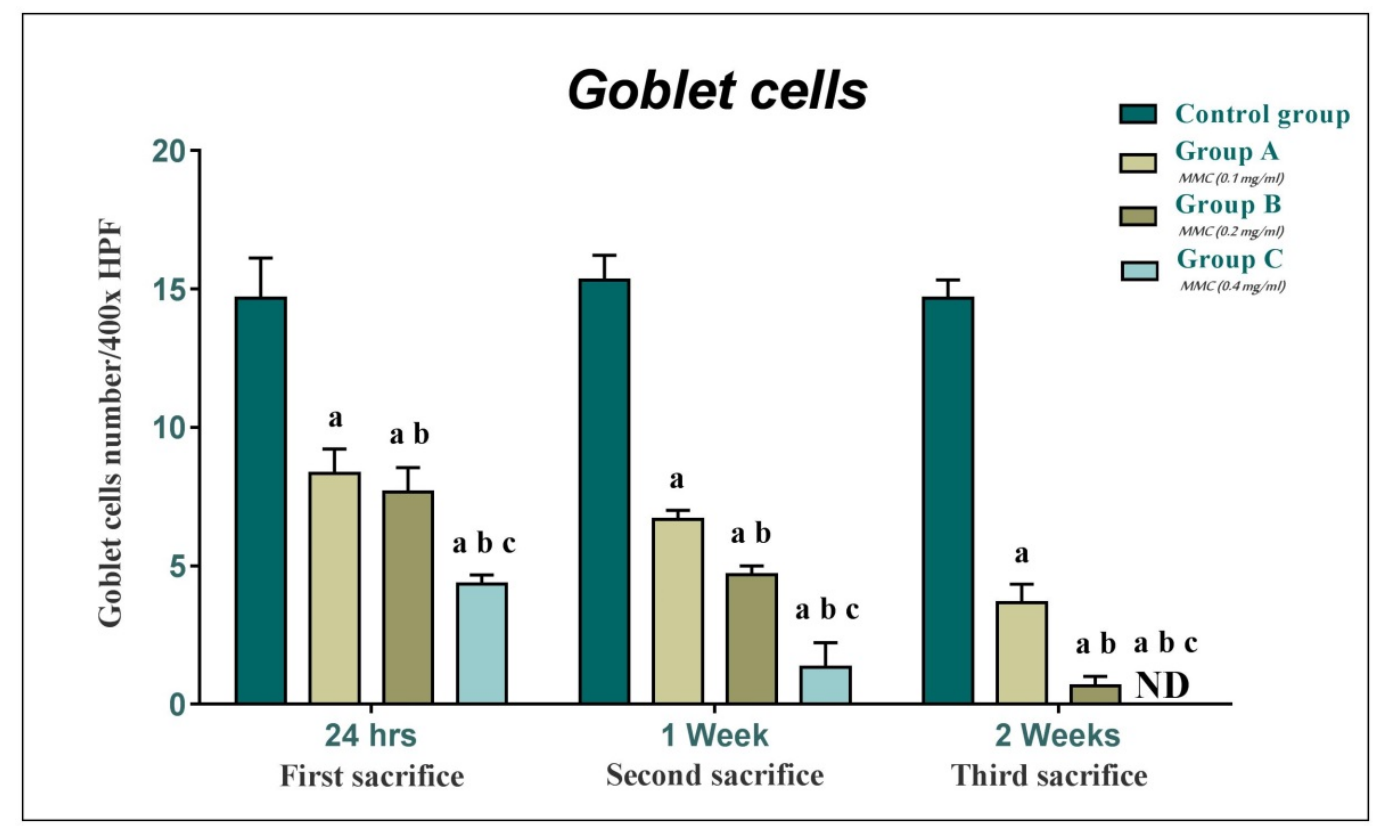

Fig. 5:A chart showing goblet cell number within the different sacrifices at different doses of mitomycin, data were expressed as mean \pm SE. ND means non-detectable cells. a indicates significance incomparing with the control group, b indicates significance incomparing with group A, c indicates significance incomparing with group B. 


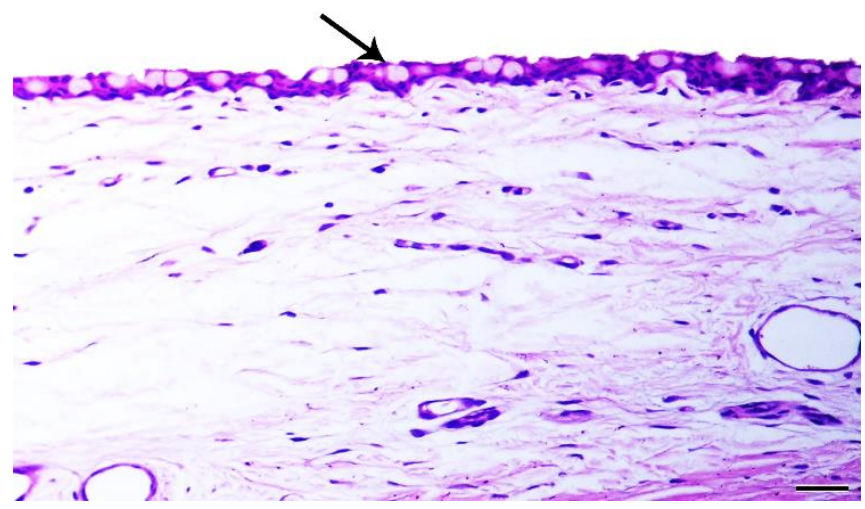

(a)

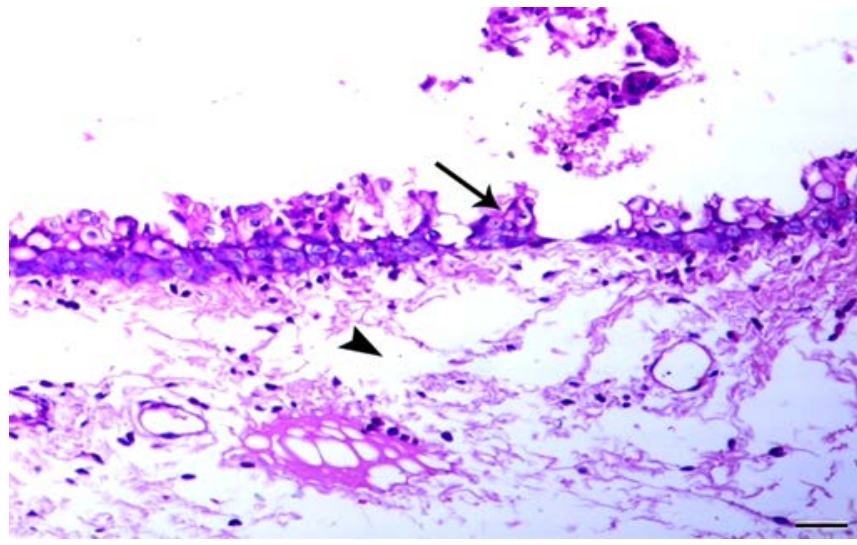

(c)

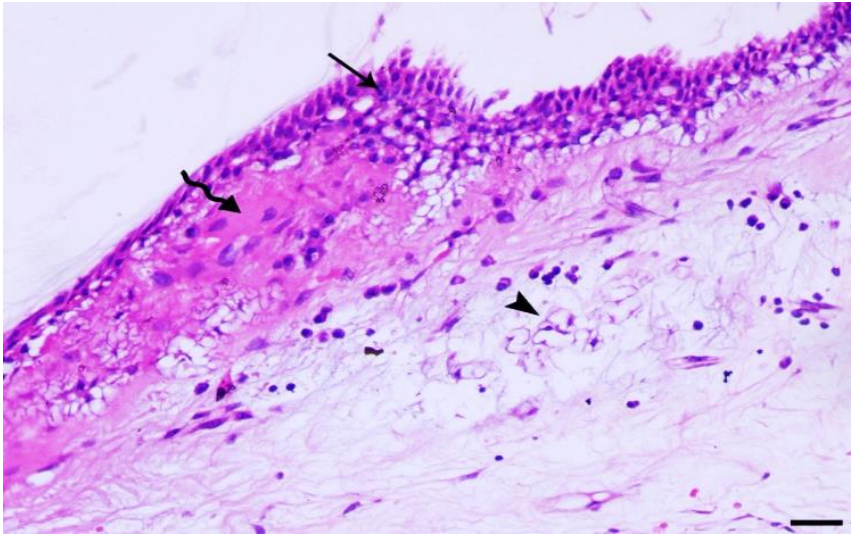

(e)

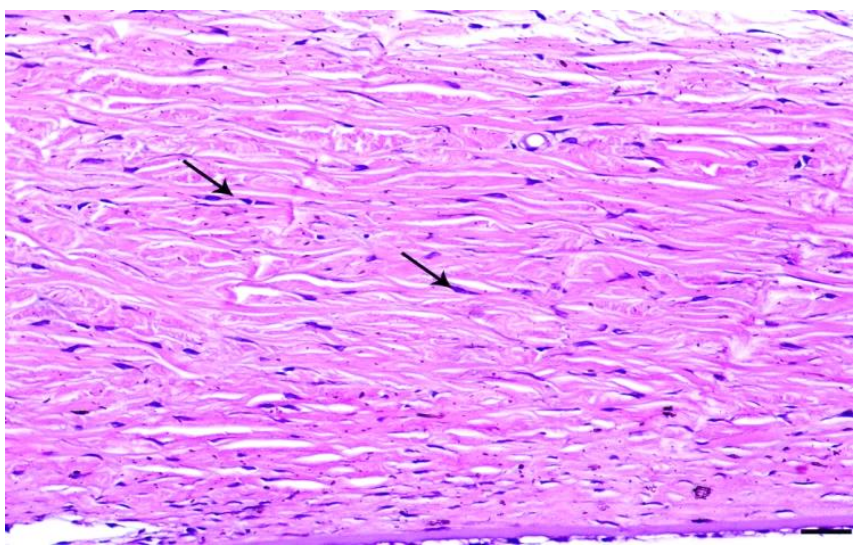

(b)

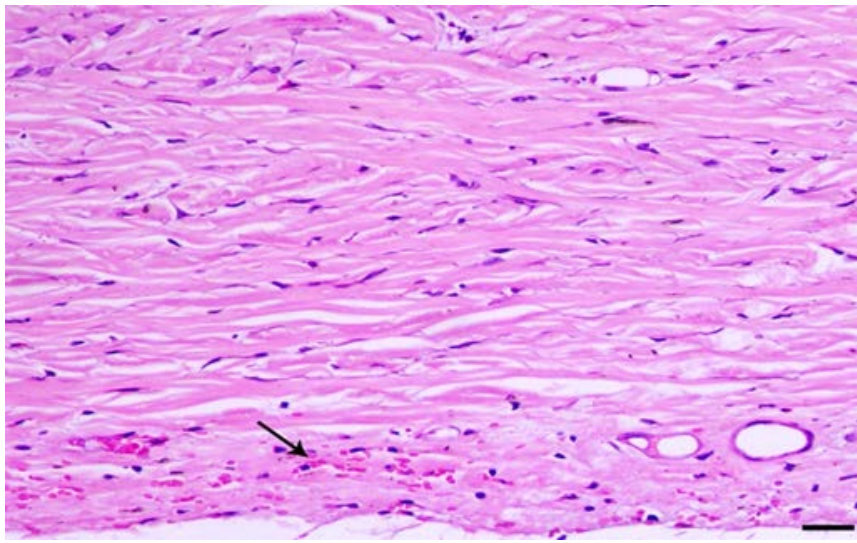

(d)

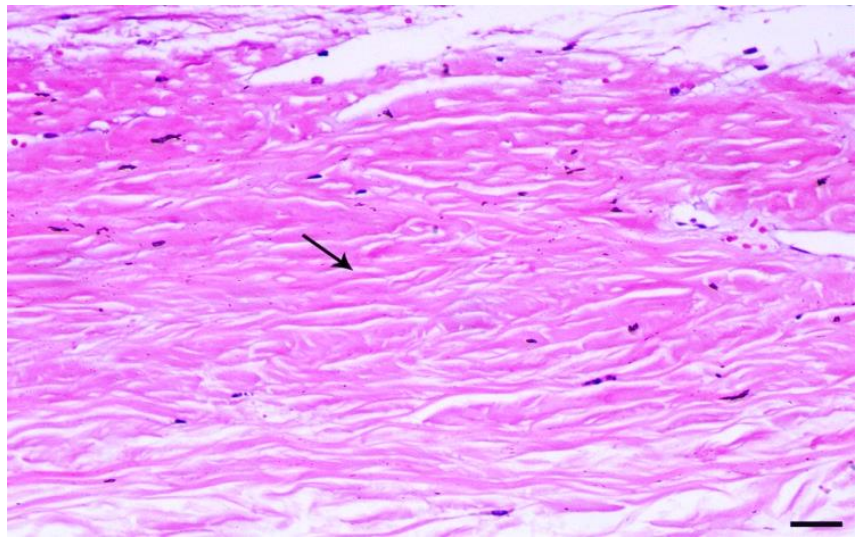

(f)

Fig. 6: H\&E stain. a;normal conjunctival section from the control group showing normal pseudostratified squamous epithelium with goblet cells (arrow), 200x, bar $=50 \mu \mathrm{m}$. b; normal scleral section from the control group showing normal stromal layer consisted of bundles of collagen fibers with fibroblasts (arrows), 200x, bar $=50 \mu \mathrm{m}$. c; $1^{\text {st }}$ sacrifice group C conjunctival section (arrow indicates degenerative changes within the epithelium, arrowhead indicates sloughing of the necrotic cells and marked edema of the epi-scleral tissue), 200x, bar $=50 \mu \mathrm{m} . \mathrm{d} ; 2^{\text {nd }}$ sacrifice group $\mathrm{B}$ scleral section (arrow indicates fibrinoid like necrosis of the most distal stromal layer accompanied with haemorrhage), 200x, bar $=50 \mu \mathrm{m}$. e; $3^{\text {rd }}$ sacrifice group C conjunctival section (arrow indicates hyperplasia of the epithelium, arrowhead indicates myxomatous changes and curved-arrow indicates syncytial cell formation), 200x, bar $=50 \mu \mathrm{m}$. $\mathrm{f} ; 3^{\text {rd }}$ sacrifice group C scleral section (arrow indicates severe loss of collagen fibers and marked decrease of fibroblasts),200x, bar= $50 \mu \mathrm{m}$. 


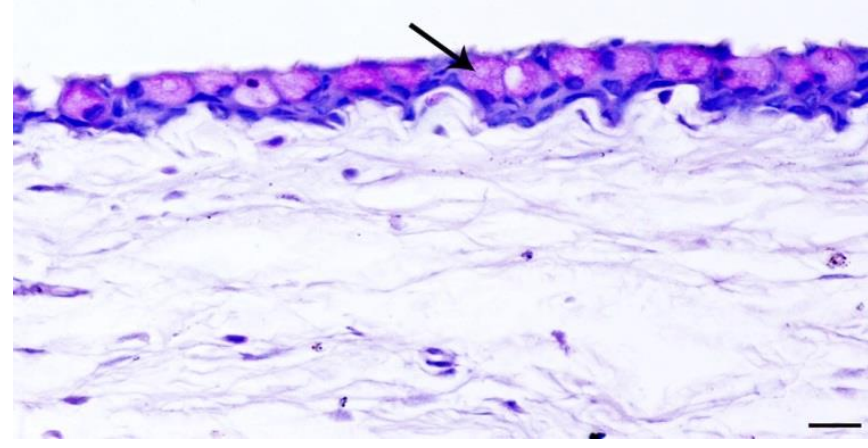

(a)

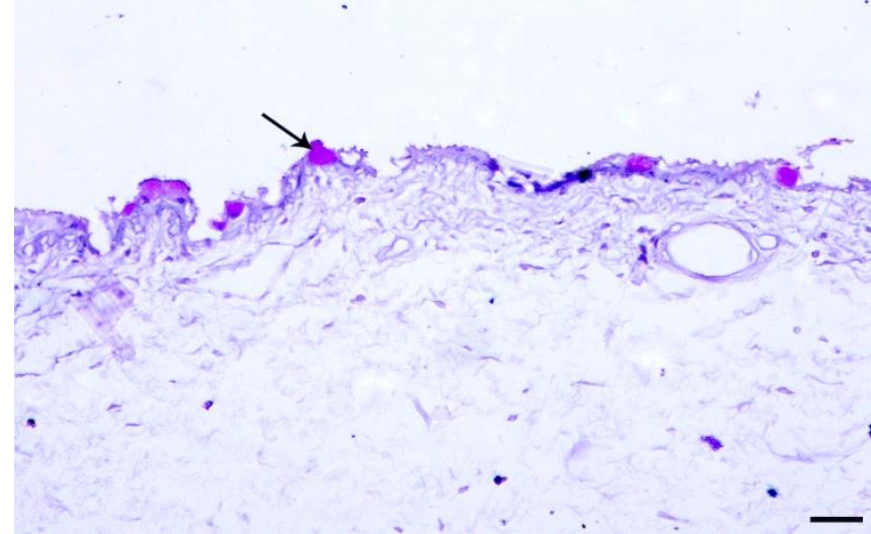

(c)

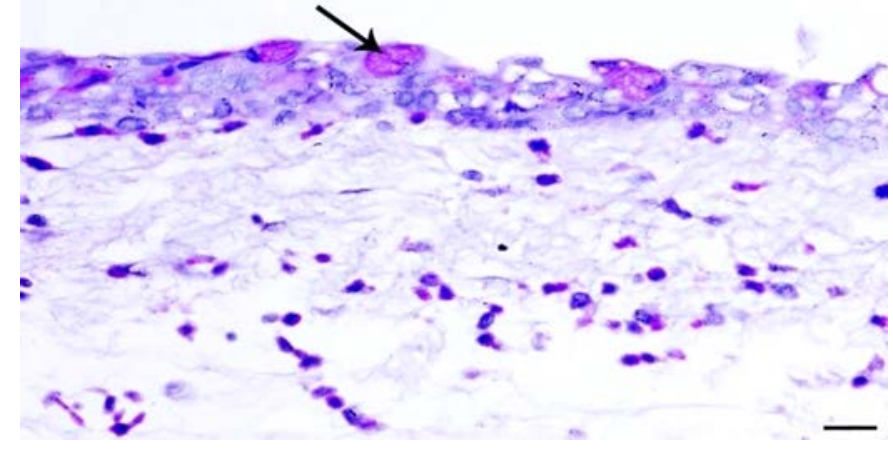

(b)

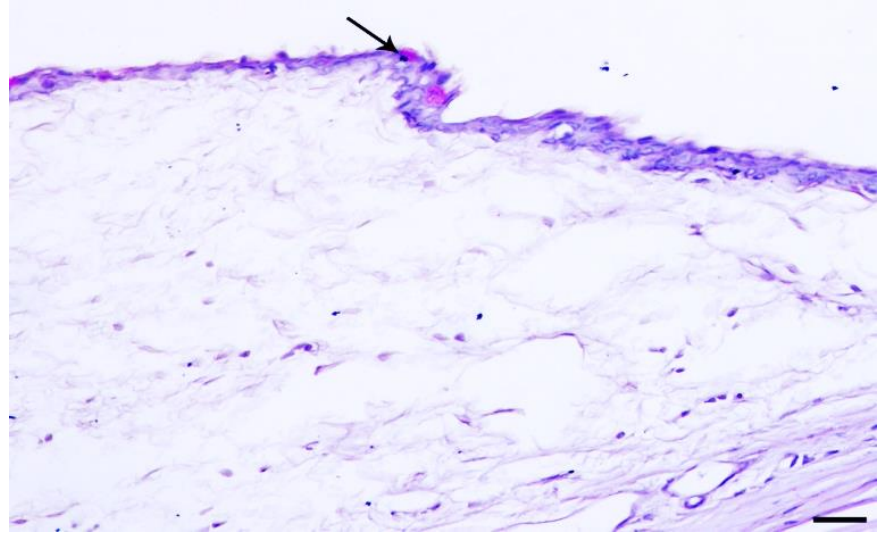

(d)

Fig. 7: PAS stain. a; normal conjunctival section from the control group showing normal and well-distributed goblet cells along the conjunctival epithelium (arrow), 400x, bar $=50 \mu \mathrm{m}$. b; $1^{\text {st }}$ sacrifice group B conjunctival section (arrow indicates marked goblet cells depletion), 400x, bar $=50 \mu \mathrm{m}$. c; $2^{\text {nd }}$ sacrifice group A conjunctival section (arrow indicates a more marked decrease of goblet cells), 200x, bar= $50 \mu \mathrm{m} . \mathrm{d} ; 3^{\text {rd }}$ sacrifice group B conjunctival section (arrow indicatessevere loss of goblet cells),200x, bar= $50 \mu \mathrm{m}$.

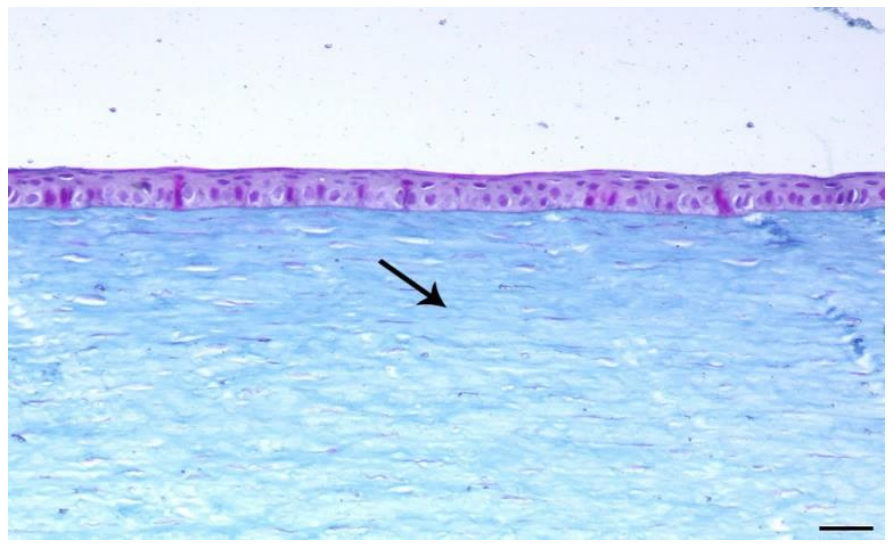

(a)

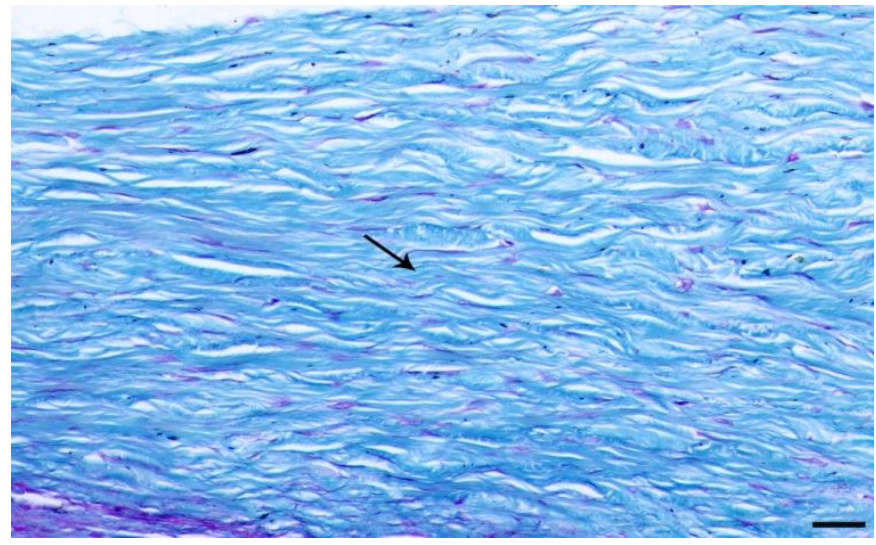

(b) 


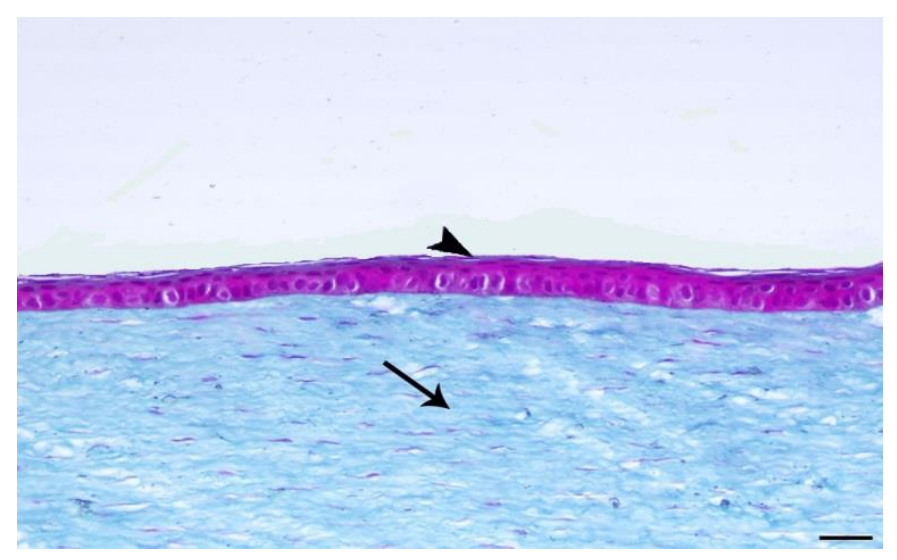

(c)

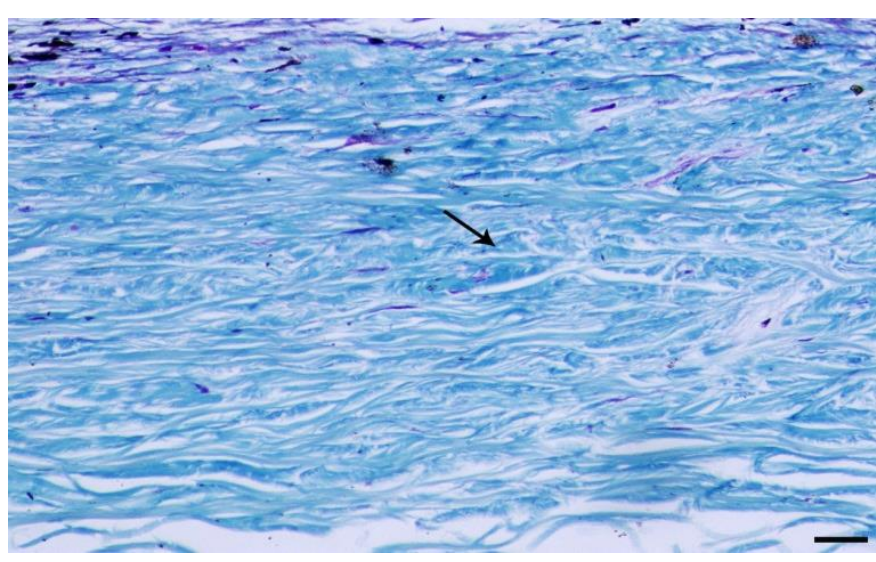

(d)

Fig. 8: MT stain. a;normal corneal section from the control group showing normal epithelium and stromal layers (arrow indicates the bluish staining of collagen fibrils), 200x, bar $=50 \mu \mathrm{m}$. b; normal scleral section from the control group showing normal stromal scleral layer consisted of a high amount of collagen fibers (arrow), 200x, bar $=50 \mu \mathrm{m}$. c; $2^{\text {nd }}$ sacrifice group B corneal section (arrow indicates normal stromal layer, arrowhead indicates a thin fibrous layer on the epithelial layer), 200x, bar $=50 \mu \mathrm{m}$. $\mathrm{d}$; $3^{\text {rd }}$ sacrifice group $\mathrm{C}$ scleral section (arrow indicates severe loss of collagen fibers), 200x, bar $=50 \mu \mathrm{m}$.

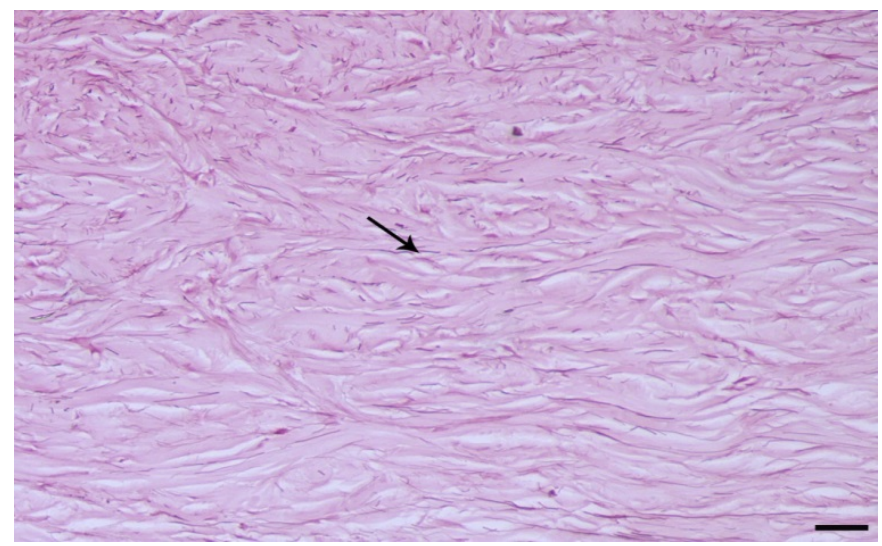

(a)

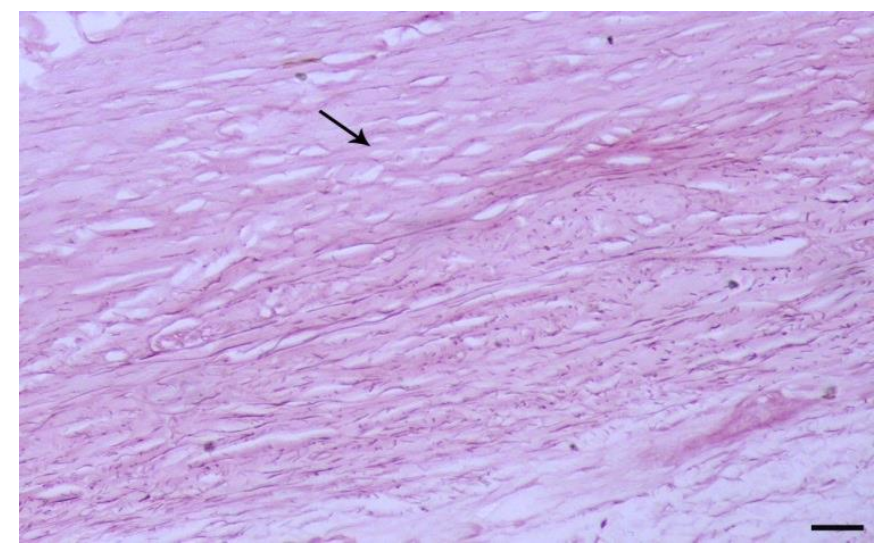

(c)

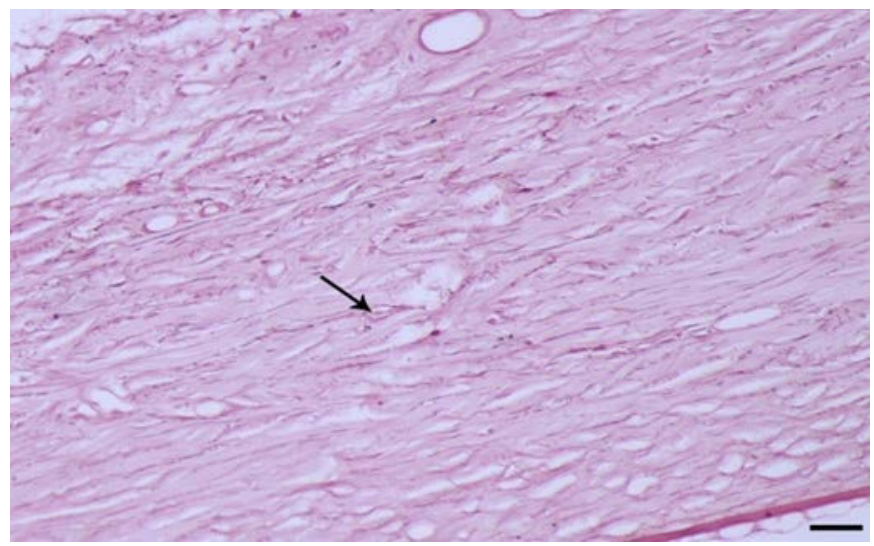

(b)

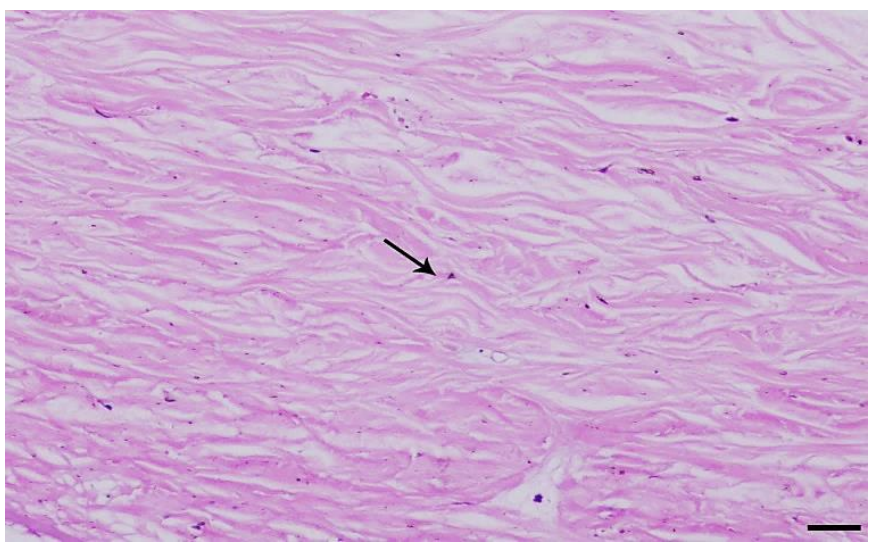

(d)

Fig. 9: Orcein stain. a; normal scleral section from the control group showing normal elastic tissue within the sclera (arrow), $200 \mathrm{x}$, bar $=50 \mu \mathrm{m} . \mathrm{b} ; 2^{\text {nd }}$ sacrifice group B scleral section (arrow indicates marked decrease of elastic tissue within the distal portion), 200x, bar $=50 \mu \mathrm{m}$. c; $3^{\text {rd }}$ sacrifice group A scleral section (arrow indicates a more marked decrease of elastic tissue), 200x, bar $=50 \mu \mathrm{m} . \mathrm{d} ; 3^{\text {rd }}$ sacrifice group C scleral section (arrow indicates severe loss of elastic tissue), $200 x, b a r=50 \mu \mathrm{m}$. 


\section{DISCUSSION}

In the current study, we aimed to assess the effects of the use of MMC when subconjunctivally injected at different concentrations ( $0.1,0.2$ and $0.4 \mathrm{mg} / \mathrm{ml})$ in rabbits by studying histopathological changes on the conjunctiva, the cornea and the sclera layers after different periodsfrom an injection of MMC (1, 7 and 14 days) for a trial to resemble preoperative injection of MMC one day (first sacrifice), one week (second sacrifice) and two weeks (third sacrifice) with the three different concentrations of MMC and recognize the possible effects on these layers.

Teus et al. ${ }^{9}$ 'human study' stated that MMC may cause vascular endothelial injuryand ischemic damage in richly vascularized tissues such as the conjunctiva or the sclera. Because the cornea is already avascular, it does not suffer from this ischemic mechanism from the MMC. No serious corneal complication has been reported after a single application of this drug during corneal surface ablation, a similar result in our study where we found that Cornea showed non-significant changes in overall thickness during the different sacrifices until the third sacrifice after 14 days when the corneal thickness was decreased with high doses of MMC $(0.4 \mathrm{mg} / \mathrm{ml})$.

When assessing the Keratocytes count in our study no significant changes were found within group A $(0.1 \mathrm{mg} / \mathrm{ml})$ and group B $(0.2 \mathrm{mg} / \mathrm{ml})$ with doses normally applied on the human cornea, similar results stated by Xu et al. ${ }^{10}$ 'animal study (rabbits)' and Midena et al. ${ }^{11}$ 'human study'.

The results of our study in keratocytes counting did not match the results of the study of Nettoet al. ${ }^{12}$ 'animal study (rabbits)' that reported time and dose-dependent decrease in keratocytes when MMC applied on rabbits corneas and the study of Safianik et al. ${ }^{13}$ 'human study' describing the severe corneoscleral complications that may occur when MMC is used as a coadjutor after pterygium excision and noting that "the consequent decreased cellular repopulation of the anterior stroma after MMC treatment, leading to an early reduction in keratocyte density and decreased collagen production, has raised concerns about its long-term effects".

De and Mukhopadhyay ${ }^{14}$ 'human study' stated that MMC inhibits mitosis, decreases cell viability and induces nuclear disorganization and giant cells in tissue culture systems. A similar finding in our study, where the corneal histological section of the group C rabbit at the first sacrifice revealed marked enlargement of the nuclei of keratocytes.

In our study regardinggoblet cells, administration of MMC at different doses even the low dose significantly decreased the goblet cells $(\mathrm{P}<0.01)$, the same result stated by Yoon et al. ${ }^{15}$ 'animal study (rabbits)' where the number of goblet cells was the lowest among all groups. MMC related complications occur in a dose and time-dependent manner, MMC is more suitable for short-term use rather than a good candidate for drug-eluting stents.

In their study, Ghoneim et al. ${ }^{16}$ 'human study' found that a scleral thinning complication occurred in one eye in each group. Group A received subconjunctival MMC 24 h. before pterygium excision and Group B with intraoperative application of MMC at pterygium excision with the bare sclera technique.

A similar result to our study, where we found that the scleral thickness decreased significantly after 2 weeks of administration of MMC $(\mathrm{P}<0.01)$ in comparison with the first and second sacrifices. The MMC dosage $(0.2 \mathrm{mg} / \mathrm{ml})$ decreased the sclera thickness after one week and two weeks $(\mathrm{P}<0.01)$. Also, the high dose of MMC significantly reduced the scleral thickness compared to the control group $(\mathrm{P}<0.01)$. As a result, the scleral thickness was markedly decreased along with the three sacrifices in a dose and time-dependent manner relative to the control group.

On the other hand, the findings of our study did not match with the findings of Alsmman et al. ${ }^{17}$ 'human study' which stated that no scleral thinning occurred over a longer follow-up period with a concentration of MMC $0.1 \mathrm{mg} / \mathrm{ml}$.

In our study, a significant decrease in fibrous connective tissue and collagen content was observed only at a high dose of MMC $(0.4 \mathrm{mg} / \mathrm{ml})$ after 24 hours of injection. During the second and third sacrifices, ocular mitomycin injection showed a significant decrease of collagen content in the dose and time-dependent manner in all treated groups $(\mathrm{P}<$ 0.01 ) and the elastic tissues within the scleral portion were markedly decreased from the first to the third sacrifice and within all treated groups in a dose and time-dependent manner $(\mathrm{P}<0.01)$.

A result was similar to that stated by Okuda et al. ${ }^{18}$ 'animal study (rabbits)' that significantly lower density of connective tissue and vascularity in the subepithelial space in MMC-only eyes compared to the control eyes.

In our study, significant conjunctival hyperemia and congestion were found in rabbit eyes treated with 0.2 and $0.4 \mathrm{mg} / \mathrm{ml}$ MMC from several hours after injection. Also, the conjunctival section of group $\mathrm{C}$ rabbit showed severe degenerative changes within the conjunctival epithelium associated with desquamation and sloughing of the necrotic cells. These findings are in line with Yoon et al. ${ }^{15}$ 'animal study (rabbits)' who reported the same signs.

\section{CONCLUSION}

In conclusion, MMC affects mainly richly vascularized tissues such as the conjunctiva and the sclera via endothelial injury and ischemic damage in time and dose-dependent manner. Yet the cornea that is already avascular does not suffer from this ischemic mechanism from the MMC. Preoperative subconjunctival injection of MMC at a concentration of $0.1 \mathrm{mg} / \mathrm{ml}$ one day before, primarily does not affect the cornea and has the least effect on the conjunctiva and sclera, making it safer and preferable when using $\mathrm{MMC}$ as a trial to prevent pterygium 
recurrence. However, large-scale studies with longer follow-up periods are required to prove this.

\section{REFERENCES}

1. Schrader S, Notara M, Beaconsfield M, et al. Tissue engineering for conjunctival reconstruction: established methods and future outlooks. Current Eye Research, 2009; 34(11): 913-924.

2. Majmudar PA, Schallhorn SC, Cason JB, et al. Mitomycin $\mathrm{C}$ in corneal surface excimer laser ablation techniques: a report by the American Academy of Ophthalmology. Ophthalmology, 2015; 122(6): 1085-1095.

3. Mearza AA and Aslanides IM. Uses and complications of mitomycin $\mathrm{C}$ in ophthalmology. Expert Opinion on Drug Safety, 2007; 6(1): 2732.

4. Chang YS, Chen WC, Tseng SH, et al. Subconjunctival mitomycin $\mathrm{C}$ before pterygium excision: an ultrastructural study. Cornea, 2008; 27(4): 471-475.

5. Mahar P. Use of mitomycin C in ocular Surgery; A Narrative Review. Pakistan Journal of Ophthalmology, 2019; 35(3): 209212.

6. Da Costa Paula C, Julio G, Campos P, et al. Effects of mitomycin C in early conjunctival inflammation after pterygium surgery. Current Eye Research, 2017; 42(5): 696-700.

7. Gupta VP, Gupta P, and Gupta R. Preoperative subpterygeal injection versus intraoperative mitomycin $\mathrm{C}$ for pterygium removal: Comparison of results and complications. American Journal of Ophthalmology, 2011; 151(2): 386-387.

8. Khan FA and Niazi SPK. Effect of pterygium morphology on recurrence with preoperative subconjunctival injection of mitomycin $\mathrm{C}$ in primary pterygium surgery. Journal of the College of Physicians and Surgeons Pakistan, 2019; 29(7): 639-643.

9. Teus MA, de Benito-Llopis L, and Alió JL. Mitomycin C in corneal refractive surgery. Survey of Ophthalmology, 2009; 54(4): 487502

10. Xu H, Liu S, Xia X, et al. Mitomycin C reduces haze formation in rabbits after excimer laser photorefractive keratectomy. Journal of Refractive Surgery, 2001; 17:34249.

11. Midena E, Gambato C, Miotto S, et al. Long term effects on corneal keratocytes of mitomycin $\mathrm{C}$ during photorefractive keratectomy: a randomized contralateral eye confocal microscopy study. Journal of Refractive Surgery, 2007; 23:1011-4.

12. Netto MV, Mohan RR, Sinha S, et al. Effects of prophylactic and therapeutic mitomycin $\mathrm{C}$ on corneal apoptosis, cellular proliferation, haze, and long term keratocyte density in rabbits. Journal of Refractive Surgery, 2006; 22:562-74.

13. Safianik B, Ben-Zion I, and Garzozi $\mathrm{H}$. Serious corneoscleral complications after pterygium excision with mitomycin C. British Journal of Ophthalmology, 2002; 86(3): 357-358.

14. De $\mathrm{P}$ and Mukhopadhyay $\mathrm{M}$. In vitro anticlastogenic and antioxidant properties of extracted and pure form of curcumin against mitomycin $\mathrm{C}$ in human peripheral leukocytes. Journal of Advanced Pharmacy Research, 2019; 3(3): 110-116.

15. Yoon SY, Kim ES, Han GS, et al. Safety and efficacy of tacrolimus-coated silicone plates as an alternative to mitomycin $\mathrm{C}$ in a rabbit model of conjunctival fibrosis. PLOS ONE, 2019; 14(7): e0226662.

16. Ghoneim EM, Abd-El Ghny AA, Gab-Allah AA, et al. Preoperative subconjunctival injection of mitomycin $C$ versus intraoperative topical application as an adjunctive treatment for surgical removal of primary pterygium. Middle East African Journal of Ophthalmology, 2011; 18(1): 37.

17. Alsmman AH, Radwan G, Abozaid MA, et al. Preoperative subconjunctival combined injection of bevacizumab and mitomycin $\mathrm{C}$ before the surgical excision of primary pterygium: clinical and histological results. Clinical Ophthalmology, 2017; 11: 493.

18. Okuda T, Higashide $\mathrm{T}$, Fukuhira $\mathrm{Y}$, et al. Suppression of avascular bleb formation by a thin biodegradable film in a rabbit filtration surgery with mitomycin C. Graefe's Archive for Clinical and Experimental Ophthalmology, 2012; 250(10): 1441-1451. 